\title{
Yulafta (Avena sativa L.) Tane Verimini Etkileyen Özelliklerin Belirlenmesi
}

\author{
${ }^{*}$ Nurgül SARI ${ }^{1}$ \\ Aydın ÜNAY2

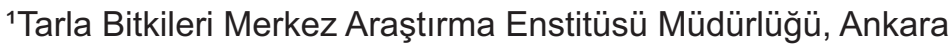 \\ ${ }^{2}$ Adnan Menderes Üniversitesi Ziraat Fakültesi Tarla Bitkileri Bölümü, Aydın \\ *Sorumlu yazar e-posta (Corresponding author; e-mail): nurgulsari@hotmail.com \\ Received (Geliş Tarihi): 17.04.2015 Accepted (Kabul Tarihi): 05.06.2105
}

\begin{abstract}
Öz
Araştırma yulafta (Avena sativa L.) verim yönünden özellikler arası ilişkilerin değerlendirilmesi amacıyla yapılmıştır. Çalışma, 2009-2010 ve 2010-2011 üretim yıllarında Ege Tarımsal Araştırma Enstitüsü (ETAE) deneme tarlalarında 2 farklı yulaf verim denemesi (YVD-1 ve YVD-2) şeklinde yürütülmüştür. Araştırma materyali olarak her bir verim denemesinde 25 genotip yer almıştır. Verim denemeleri, tesadüf blokları deneme deseninde dört tekerrürlü olarak kurulmuştur. Bu denemelerden elde edilen ortalama değerler üzerinden verim ve verim öğeleri arasındaki ilişkiler korelasyon ve path analizine göre değerlendirilmiştir. Araştırmada protein, yağ, nişasta, besinsel lif, beta glukan, kavuz oranı, kül, bitki boyu, tane iriliği, hasat indeksi, salkım boyu, salkımda başakçık sayısı, salkımda tane sayısı, salkımda tane ağırlığı, bin tane ağırığı, hektolitre ağılığı ve tane verimi kriterleri incelenmiştir. Elde edilen sonuçlara göre; tane verimi ile hektolitre ağırlığı, bin tane ağırlığı, tane iriliği, hasat indeksi arasında önemli ve pozitif yönde korelasyon bulunmuştur. Path analizinde verim ile olan doğrudan etkiler incelendiğinde, sırasıyla hasat indeksi, salkımda tane ağırlığı, hektolitre ağırlığı, nişasta, protein, salkım boyu, salkımda başakçık sayısı ve bitki boyu özelliklerinin yüksek olumlu yönde değerler taşıdığı görülmüştür. Korelasyon ve Path analizi sonuçlarının aynı doğrultuda olduğu saptanmış ve tane verimi için yapılacak ıslah çalışmalarında hasat indeksi, salkımda tane ağırlığı ve hektolitre ağırlığının seleksiyon ölçütü olarak kullanılabileceği sonucuna varılmıştır.
\end{abstract}

Anahtar Sözcükler: Yulaf (Avena sativa L.), tane verimi, korelasyon, path analizi.

\section{Determining Characteristics Affecting Grain Yield of Oats (Avena sativa L.)}

\begin{abstract}
Research was conducted at the experimental fields of Aegean Agricultural Research Institute (AARI) to determine the relationship between yield and yield components of oat (Avena sativa L.) in 2009-2010 and 20102011 two yield trials (OYT-1 and OYT-2). There were 25 genotypes in each trial. Experimental design was completely randomized block design with four replications in the both trials. This relationship between the mean values obtained on yield and yield components were evaluated according to the test correlation and path analysis. The rates of protein, oil, starch, nutritious fiber, beta glucan, glume, and ash in grain; addition, plant height, grain size, harvest index, panicula height, number of spikelet in a panicula, number of grain in a panicula, grain weight in panicle, thousand kernel weight, test weight and grain yield were evaluated. According to the results; the correlations between yield and yield components including test weight, thousand kernel weight, grain size and harvest index were positive and significantly important. Harvest index had the highest correlation coefficient. Harvest index, grain weight in panicula, test weight, starch, protein, panicula height, number of spikelet in a panicula and plant height had positive and significant direct effect on grain yield. Correlation and Path analysis results suggested that harvest index, grain weight in a panicula and test weight be needed to be raised for higher grain yield.
\end{abstract}

Keywords: Oat (Avena sativa L.), grain yield, correlation, path analysis.

\section{Giriş}

G ramineae familyasında yer alan ve tek yıllık olan yulaf iyi bir protein, lif ve mineral içeriği ile hem insan hem de hayvan beslenmesinde kullanılmaktadır. Diğer tahıl türlerine göre üzerinde yürütülen ıslah çalışmaları daha az sayıdadır. Tane verimi yönünden yapılacak ıslah çalışmalarında ıslah materyalinin tanımlanması ve seleksiyon ölçütlerinin belirlenmesinde 
özellikler arası ilişkilerin saptanması gerekmektedir. Tane verimi çok sayıda fizyolojik ve morfolojik karakterlerin karşılıklı etkileşimleri sonucu oluşmaktadır (Öztürk ve Atken 1999). Bu nedenle, ıslah çalışmalarında özellikler arasındaki ilişkiler ve korelasyon katsayıları kullanılmakta, ancak daha çok birbirinden bağımsız karakterler arasındaki ilişkileri ortaya koymaktadır. Korelasyon katsayısının ıslahçıların amacına ulaşmasında yetersiz kalmasından dolayı Dewey ve Lu (1959) tarafından geliştirilen ve path analizi olarak bilinen kısmi regresyon analizi yöntemi kullanılabilmektedir.

Çeşitli araştırmalarda basit korelasyon katsayıları kullanılarak tane verimi ile agronomik ve morfolojik karakterler arasındaki ilişkiler açıklanmaya çalışılmıştır. Basit korelasyon katsayıları tane verimini belirleyen ana verim öğelerinin ortaya çıkarılmasında yararlı ise de, basit korelasyon katsayıları birbirleriyle karmaşık ilişkiler içerisinde olan değişik karakterlerin verim üzerine doğrudan ve dolaylı etkilerini tam olarak ifade edememektedir (Bhat 1973). Verimi etkileyen öğelerin hepsi verim üzerine doğrudan doğruya etki göstermemekte, kendi aralarındaki ilişkilerin sonucu dolaylı olarak da etkide bulunabilmektedir. Bu nedenle başarılı bir ıslah programı için bu karakterlerin doğrudan ve dolaylı etkileşim derecelerinin birbirinden ayrılması ve ayrıntılı bir şekilde ortaya konulması path analizi ile mümkün olabilmektedir (Dofing ve Knight 1992; Mohamed 1999).

Micke (1979), verimin ve diğer kantitatif özelliklerin ıslahında; verimi arttıran ya da sınırlandıran öğelerinin belirlenmesi ve bu yönde varyasyon oluşturarak seleksiyon uygulanmasının ıslahçıyı başarılı kılacağını belirtmiştir. Tane veriminin, vejetasyonun farklı devrelerinde söz konusu öğelerinin değişik orandaki katkılarıyla ortaya çıktığı düşünüldüğünde, yüksek verimli genotiplerin geliştirilmesini amaçlayan ıslah programlarında, bu faktörlerin verimi nasıl etkilediğinin bilinmesi gereklidir (Altınbaş ve Sepetoğlu 1993).

Özellikler arasında ilişkilere ait bilgilerin yetersiz oluşu ve genellikle tarımsal özelliklerin seleksiyonun tek yanlı olarak yapılması, bitki ıslahında çoğu zaman beklenen kazancı getirmemiştir (Bhatt 1973). Bu ilişkilerin belirlenmesinde yaygın olarak kullanılan korelasyon ve regresyon analizlerine nazaran path, faktör ve stepwise analizleri özellikler arası ilişkileri daha ayrıntılı olarak açıklayabilmektedir. Ayrıca araştırmada bu yöntemlerden birkaçının birlikte kullanıması halinde birbirini tamamlayıcı nitelikte sonuçlar elde edildiği bilinmektedir.

Yulafta özellikle yeşil ot verimi üzerine yapılan değerlendirmelerde, ot veriminin bitki boyu, yaprak uzunluğu, genişliği ve gövde kalınlığı ile yüksek oranda pozitif ilişkide olduğu ve yeşil yem verimi üzerine en büyük doğrudan olumlu etkiye bitki boyu ve yaprak genişliğinin sahip olduğu bulunmuştur (Choubey ve Grupta 1986). Bir başka çalışmada ise Bahl ve ark. (1988), bitkide kuru madde verimi, yeşil yem verimi ve günlük kuru madde artışı arasında pozitif korelasyonlar belirlediklerini, bitkide yeşil yem verimi ile yaprak sayısı ve gövde kalınlığı, bitkide yaprak sayısı ile günlük yeşil yem ve kuru madde artışı arasında olumlu ilişkiler bulunduğunu ve uyguladıkları path analizi ile bitkide yeşil yem verimini etkileyen doğrudan ve dolaylı özelliklerin, farklı çevrelerde önemli ölçüde değiştiğini tespit etmişlerdir. Acar (1994) ise kuru ot verimi ile verim öğeleri arasındaki ilişkilerin korelasyon ve path analizi ile belirlenmesi konusunda yapmış olduğu bir çalışmada; bitkide kuru ot verimi yönünden yapılacak seleksiyon çalışmalarında, yaprak ayası uzunluğu ve genişliği ile bitki boyu üzerinde durulması gerektiği, çünkü bu karakterlerin kuru ot verimini en çok olumlu yönde etkileyen karakterler olduğunu belirtmiştir.

Tane verimi yönünden yapılan çalışmalarda ise lannucci ve ark. (2011), özellikler arası korelasyon katsayılarına göre verim ile başaklanma gün sayısı, olgunlaşma gün sayısı ve bitki boyu arasında olumsuz ve önemli; verim ile hasat indeksi, salkımda tane ağırlığı ve bin tane ağırlığı arasında olumlu ve önemli ilişkiler saptamıştır. Tane verimi için yüksek hasat indeksi, yüksek bin tane ve hektolitre ağırlığı, yeşil yem için uzun, yapraklı bitki ve düşük hasat indeksinin önemli olduğunu bildirmişlerdir. Dumlupınar ve ark. (2008), path analizi sonucu, en yüksek doğrudan etkileri bitki boyu ve salkımda tane ağırlığı için negatif, buna karşın birim alanda salkım sayısı, bin tane ağırlığı ve salkımda tane sayısı için pozitif yönde bulmuşlardır.

Önceki çalışmalarda verim yönünden değerlendirilen özellikler arasında kalite özelliklerinin yer almadığı dikkati çekmektedir. Bu nedenle, bu çalışmada yulafta (Avena sativa L.) verim ve verim öğeleri yanında protein, nişasta, besinsel lif içeriği ve beta glukan gibi kalite özellikleri tespit edilmiştir. İki yıl ve toplam 50 genotipten oluşan değişken sayısı üzerinden özellikler arası ilişkiler korelasyon ve path analizi ile değerlendirilmiştir. 


\section{Materyal ve Yöntem}

Çalışma, 2009-2010 ve 2010-2011 üretim yıllarında ETAE (Ege Tarımsal Araştırma Enstitüsü) deneme tarlalarında 2 farklı yulaf verim denemesi (YVD-1 ve YVD-2) şeklinde yürütülmüştür. Araştırma materyali olarak her bir verim denemesinde 25 genotip yer almıştır. YVD-1 de farklı orijin ve kökenden gelen 20 ileri hat ve 5 standart yulaf çeşidi; YVD-2 de ise 19 ileri hat ve 6 standart yulaf çeşidi kullanıımıştır. Materyalin kaynağını; Ege Tarımsal Araştırma Enstitüsü Bitki Genetik Kaynakları Bölüm Başkanlığınca Ulusal Gen Bankası kanalı ile yurt dışından getirtilen introdüksiyon materyali oluşturmuştur. Standart olarak kullanılan yulaf çeşitlerini ise Ege Bölgesi sahil kuşağında ekilen bir adet köy populasyonu (Ak yulaf) ve tescilli yulaf çeşitleri olan Apak 2-3, Bozkır 1-5, Checota, Faikbey, Seydişehir ve Yeşilköy330 oluşturmuştur. Günümüzde bu çeşitlerden sadece Seydişehir ve Faikbey çeşitlerinin tohumluk üretimi yapılmaktadır.

Ekimler, Ege Tarımsal Araştırma Enstitüsü deneme tarlalarında 2009-2010 üretim döneminde 01 Aralık 2009 ve 2010-2011 üretim döneminde 30 Kasım 2010 tarihinde yapılmıştır. Deneme deseni 4 tekerrürlü tesadüf bloklarıdır. Parseller $5 \mathrm{~m}$ uzunluğunda 8 sıradan $(1.2 \mathrm{~m})$ oluşmuştur. Blokların başında ve sonunda olmak üzere iki sıra Ak yulaf köy popülasyonu ekilmiştir. Hasat 2009-2010 üretim döneminde 21 Haziran 2010, 2010-2011 üretim döneminde 28 Haziran 2011 tarihinde, salkımların tam olgunlaştığı dönemde parsel biçerdöveri ile yapılmıştır.

Araştırmamızda; protein, yağ, nişasta, besinsel lif, beta glukan, kavuz ve kül ile bitki boyu, tane iriliği, hasat indeksi, salkım boyu, salkımda başakçık sayısı, salkımda tane sayısı, salkımda tane ağırlığı, bin tane ağırlığı, hektolitre ağırlığı ve tane verimi kriterleri incelenmiştir. Protein oranı; hasat sonrası her parselden elde edilen tanelerin değirmende ögütülmesi ve Dumas yakma yöntemine göre tanedeki protein oranının ölçülmesiyle saptanmıştır (Leco FP328; AACC Method 4630.01). Yağ oranı; Sokselet cihazında, yağ çözücü (eter) ile ekstrasyona tabi tutulması esasına göre, tanedeki yağ oranının ölçülmesiyle bulunmuştur (Gerhardt Therm 2000, Germany). Nişasta oranı; hasat sonrası her parselden elde edilen tanelerin değirmende ögütülmesi ve hazır kitler kullanılarak (AOAC Method 996.11; Megazyme, Ireland), besinsel lif oranı; (AOAC 991.43; Megazyme, Ireland), beta glukan oranı; (AOAC Method 995.16; Megazyme, Ireland) metodlarının uygulanması ile belirlenmiştir. Kavuz oranı, hasat sonrası her parselden elde edilen 50 adet tanede, Luff metoduna göre hesaplanarak elde edilmiştir (Gökgöl,1969). Kül oranı; AACC metot 08-01'u yulaf örneklerine modifiye edilerek saptanmıştır. Bitki boyu; olgunluk döneminde, toprak seviyesinden salkımın en üst noktasına kadar olan mesafe ölçülerek, tane iriliği; Sortimat marka elek tartım sonuçlarına göre, 2.5 mm'nin üzerinde kalan yulafların yüzdeleri hesaplanarak elde edilmiştir. Hasat indeksi; tohum olgunlaşma döneminde tane ağırlığı tüm toprak üstü aksamının ağırlığına bölünerek tespit edilmiştir. Salkım boyu; deneme parsellerinden tesadüfi olarak seçilen, 10 adet salkımın dip kısmından ucuna kadar ölçülmesi ve ortalamasının alınması, salkımda başakçık sayısı; 10 adet salkımın başakçıklarının sayılması ve ortalamasının alınması, salkımda tane sayısı; 10 adet salkımın harman edilerek, elde edilen tanelerin sayılması ve ortalamasının alınması, salkımda tane ağırlığı; 10 adet salkımın harman edilerek, elde edilen tanelerin tartılması ve ortalamasının alınmasıyla elde edilmiştir. Bin tane ağırlığı; hasat sonrası her parselden elde edilen taneler, dört tekrarlamalı olarak 100'er tane sayılıp tartılmış, ortalaması alınıp 10 ile çarpılarak bulunmuştur. Hektolitre ağırlığı; hasat sonrası KETT-PM 600 aleti ile tartım yapılarak saptanmıştır. Tane verimi ise denemede parsel verimi dekara $(\mathrm{kg} / \mathrm{da})$ çevrilerek tespit edilmiştir.

Her iki denemede incelenen özelliklere ait değerlerin iki yıllık ortalamaları kullanılarak çok değişkenli analizler yapılmıştır. Özellikler arası korelasyon katsayılarının ve path katsayılarının belirlenmesinde TARIST istatistik paket programı kullanılmıştır (Açıkgöz ve ark. 1994). Yapılan analiz ile incelenen özelliklerin tane verimine doğrudan ve dolaylı etkileri belirlenmiştir (Dewey ve Lu 1959; Li 1968).

\section{Bulgular ve Tartışma}

Korelasyon Katsayıları: Menemen ekolojik koşullarında iki yıllık çalışma sonucu; verim ile hektolitre ağırığı, bin tane ağırlığı, tane iriliği, hasat indeksi, salkımda başakçık sayısı, salkımda tane sayısı, salkımda tane ağırlığı, nişasta, yağ, protein, beta glukan ve kül oranları arasında önemli pozitif korelasyon belirlenmiştir (Çizelge 1). 


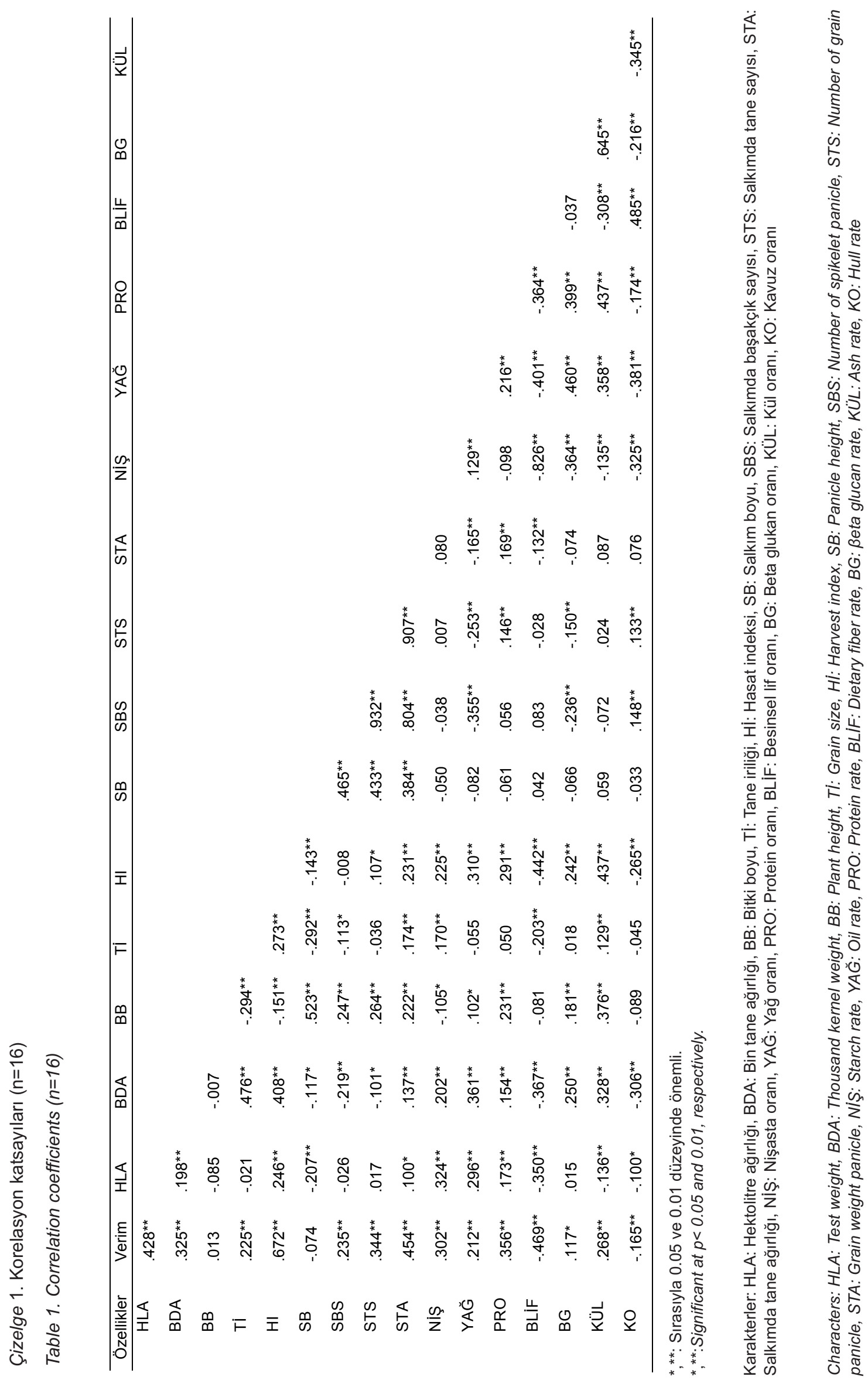


Verim ile besinsel lif ve kavuz oranı arasında ise önemli negatif korelasyon tespit edilmiştir. Benzer şekilde, lannucci ve ark. (2011), Akdeniz iklim kuşağına uyumlu yulaf germplazmının genel özelliklerini tanımlamak amacıyla iki yıl süre ile İtalya'da yürüttükleri çalışmada verim ile hasat indeksi, salkımda tane ağırlığı ve bin tane ağırlığı arasında olumlu ve önemli ilişkiler saptamışlardır.

Yulaf üzerine yürütülen bir çok çalışmada bitki boyu ile tane verimi arasında önemli negatif korelasyonlar tespit edilmiştir (lannucci ve ark. 2011; Buerstmayr ve ark. 2007; Dumlupınar ve ark. 2008; Redaelli ve ark. 2008). Ancak çalışmamızda bitki boyu ile verim arasında önemsiz olmasına rağmen pozitif bir ilişki saptanmıştır. Bilindiği üzere bitki boyu ile yatma arasında pozitif önemli ilişki bulunmaktadır. Bu da tane verim kaybına neden olmaktadır (Buerstmayr ve ark. 2007). Çalışmamızda bitki boyu ile verim arasında önemli negatif korelasyon tespit edilememesi denemenin yürütüldüğü yer ve yıl koşullarından kaynaklanıyor olabileceği gibi genetik etkinin de söz konusu olabileceği düşünülmektedir.

lannucci ve ark. (2011), verim ile hektolitre ve salkımda tane ağırlığı arasında korelasyonu pozitif olarak belirlemişlerdir. Salkımda tane ağırlığı verimli bir yulaf genotipini tespit etmek için oldukça önemli özelliklerden birisi olarak kabul edilmektedir (Peltonen-Sainio 1991). Burada yürütülen çalışmada da benzer şekilde hektolitre ve salkımda tane ağırlığı ile verim arasında pozitif ve önemli korelasyon tespit edilmiştir.

Hektolitre ağırığı ile bin tane ağırlığı, hasat indeksi, salkımda tane ağırlığı, nişasta, yağ, protein oranı arasında önemli pozitif, buna karşın, hektolitre ağırlığı ile salkım boyu, besinsel lif, kül ve kavuz oranı arasında önemli negatif korelasyon olduğu görülmektedir. Bin tane ağırlığı ile tane iriliği, hasat indeksi, salkımda tane ağırlığı, nişasta, yağ, protein, beta glukan ve kül oranı arasında önemli pozitif korelasyon bulunurken, bin tane ağırlığı ile salkım boyu, salkımda başakçık sayısı, salkımda tane sayısı, besinsel lif ve kavuz oranı arasında önemli negatif korelasyon belirlenmiştir.

Bitki boyu ile salkım boyu, salkımda başakçık sayısı, salkımda tane sayısı, salkımda tane ağırlığı, yağ, protein, beta glukan ve kül oranı arasında önemli pozitif, ancak bitki boyu ile tane iriliği, hasat indeksi ve nişasta oranı arasında önemli negatif korelasyon görülmektedir. Tane iriliği ile hasat indeksi, salkımda tane ağırıı̆ı, nişasta ve kül oranı arasında önemli pozitif, tane iriliği ile salkım boyu, salkımda başakçık sayısı ve besinsel lif oranı arasında önemli negatif korelasyon bulunmuştur. Hasat indeksi ile salkımda başakçık sayısı arasındaki korelasyon dışındakilerin önemli olduğu, aynı özelliğin salkımda tane sayısı, salkımda tane ağırlığı, nişasta, yağ, protein, beta glukan ve kül arasındaki korelasyonun pozitif buna karşın diğer özelliklerin negatif yönde korelasyon taşıdığı görülmektedir. lannucci ve ark. (2011), araştırmalarında hasat indeksi ile salkımda tane sayısı, salkımda tane ağırlığı ve bin tane ağırlığı arasında pozitif korelasyon tespit etmişler, çalışmadaki sonuçlar ile bu durum uyum içerisinde bulunmuştur.

Salkım boyu ile sadece salkımda başakçık sayısı, salkımda tane sayısı ve salkımda tane ağırlığı arasındaki korelasyon katsayılarının önemli pozitif olduğu görülmektedir. Salkımda başakçık sayısı ile ise salkımda tane sayısı, salkımda tane ağırlığı ve kavuz oranı arasında önemli pozitif korelasyon, buna karşın aynı özellik ile yağ ve beta glukan arasında önemli negatif korelasyon saptanmıştır. Salkımda tane sayısı ile salkımda tane ağırlığı, protein ve kavuz oranı arasında önemli pozitif, ancak yağ ve beta glukan arasında önemli negatif korelasyon bulunmuştur. Salkımda tane ağırlığı ile sadece protein oranı arasında önemli pozitif, buna karşın yağ ve besinsel lif oranı arasında önemli negatif korelasyon belirlenmiştir.

Nişasta oranı ile yağ oranı arasında önemli pozitif, aynı özelliğin besinsel lif, beta glukan, kül ve kavuz oranı ile olan korelasyonun önemli negatif yönde olduğu saptanmıştır. Yağ oranının protein, beta glukan ve kül oranı ile olan korelasyonun önemli pozitif yönde olduğu buna karşın aynı özelliğin besinsel lif ve kavuz oranı arasında ise negatif önemli korelasyon taşıdığı görülmektedir. Protein oranı ile beta glukan ve kül oranı arasında önemli pozitif, besinsel lif ve kavuz oranı ile arasında ise önemli negatif korelasyon bulunmuştur. Besinsel lif oranı ise kül oranı ile önemli negatif, kavuz oranı ile önemli pozitif korelasyon taşımaktadır. Beta glukan ile kavuz oranı arasında önemli negatif korelasyon saptanırken beta glukan ve kül oranı arasında önemli pozitif korelasyon katsayıları olduğu söz konusu tablodan görülmektedir. 
Beta glukan ile verim, bin tane ağırlığı, bitki boyu, hasat indeksi, yağ, protein ve kül miktarı arasında olumsuz ve önemli, buna karşın; beta glukan ile salkımda başakçık sayısı, salkımda tane sayısı, nişasta ve kavuz oranı arasında olumsuz ve önemli korelasyon katsayıları saptanmıştır. Beta glukan içeriğinin verim ile önemli korelasyonlar taşımadığı (Holthaus ve ark.1996; Kibite ve Edney 1998) bildirilmiştir. Çalışmamızda ise olumlu ve önemli korelasyon katsayısına sahip olduğu görülmektedir. Özellikler arası fenotipik korelasyonların hem genetik hem de çevresel etkilere bağlı olması çalışmalarda ele alınan genotip ve çevre farklıı̆ı̆ından ileri gelen sonuç farklılıklarını ortaya çıkarmaktadır. Ancak, beta glukan ile bin tane ağırlığı ve protein içeriği arasındaki önemli ve olumlu yöndeki korelasyonlar Peterson ve ark. (1995); beta glukan ile kavuz oranı arasındaki olumlu ve önemli korelasyonlar Holthaus ve ark. (1996) tarafından bulunan sonuçlar ile örtüşür niteliktedir.

Path Analizi: Verim ile olan doğrudan etkiler incelendiğinde sırasıyla hasat indeksi, salkımda tane ağırlığı, hektolitre ağırlığı, nişasta oranı, protein oranı, salkım boyu, salkımda başakçık sayısı ve bitki boyu özelliklerinin yüksek ve olumlu yönde değerler taşıdığı görülmektedir. Bu özelliklerin diğer özellikler üzerinden olan dolaylı etkilerinin değerlendirilmesi yapıldığında; hasat indeksinin, salkımda tane ağırığı ve hektolitre ağırlığı üzerinden yüksek ve olumlu; salkımda tane ağılığının hasat indeksi ve salkımda başakçık sayısı üzerinden yüksek ve olumlu; hektolitre ağırlığının nişasta oranı üzerinden yüksek ve olumlu dolaylı etkiler taşıdığı belirlenmiştir. Aynı şekilde nişasta oranı hasat indeksi ve hektolitre ağırlığı üzerinden yüksek ve olumlu buna karşın besinsel lif oranı üzerinden olumsuz dolaylı etkilere sahiptir. Protein oranının hasat indeksi üzerinden salkım boyunun ise salkımda tane ağırlığı üzerinden olumlu, ancak hasat indeksi üzerinden olumsuz dolaylı etkilere sahip olduğu görülmektedir. Salkımda başakçık sayısının ise salkımda tane ağırlığı üzerinden olumlu, salkım boyu üzerinden olumsuz dolaylı etkiler taşımaktadır. Bitki boyunun salkımda tane ağırlığı üzerinden olumlu buna karşın hasat indeksi ve salkım boyu üzerinden olumsuz dolaylı etkiler taşıdığı söylenebilir (Çizelge 2).

Dumlupınar ve ark. (2008), bazı yulaf genotiplerinin tane verimi ve verim öğelerinin korelasyonu ve path analizi isimli çalışmalarında, salkımda tane sayısı ve bin tane ağırlığının verim üzerine yüksek ve olumlu, bitki boyu ve salkımda tane ağırlığının yüksek fakat olumsuz yönde etkisini saptamışlardır. Araştırıcılar bu araştırmada tespit edilenin aksine salkımda tane ağırlığının ve bitki boyunun verim üzerine önemli negatif doğrudan etkileri olduğunu belirlemişlerdir. Bu durum genetik veya çevre şartlarındaki farklılıklardan kaynaklanmış olabilir. Leilah ve ark. (2005), kurak şartlarda buğdayda, bitki boyunun tane verimi üzerine olan doğrudan etkisinin olumlu olduğunu, Kara ve Akman (2007), yerel buğdaylarla ile yaptığı çalışmalarında, tane verimi ile bitki boyu arasında olumlu ve önemli ilişkiyi saptamışlardır. Bu durum çalışmamızda bitki boyunun verim üzerine doğrudan etkisi (\%19.97) açısından elde edilen bulgular ile örtüşmektedir. Moradi ve ark. (2005), verim üzerine en büyük doğrudan etkiyi $\mathrm{m}^{2}$ 'de ki bitki sayısı ve salkımdaki tane sayısının yaptığını tespit etmişlerdir. Çalışmamızda bin tane ağırlığının verim üzerine düşük oranda (\% 0.08) pozitif doğrudan etkisinin olduğu belirlenmiştir. Bin tane ağırlığının verim üzerine etkisinin değişken olduğu, bazı çalışmalarda pozitif doğrudan etki belirlenirken, bazılarında negatif doğrudan etki tespit edilmiştir (Yang 1986; Ram 1992; Mehetre ve ark. 1994; Samonte ve ark. 1998; Sürek ve ark. 1998). Bhutta ve ark. (2005) bin tane ağırlığının verim üzerine etkisinin negatif dolaylı olduğunu saptamışlardır. Bu çalışmada bin tane ağırlığının hasat indeksi üzerinden önemli dolaylı pozitif etkisi (\% 44.23) olduğu da belirlenmiştir. Genç (1978), başakta tane sayısı ve tane ağırığının tane verimi ile oldukça yakın ilişkili olduğunu tespit etmiştir. Kumbhar ve ark. (1983) ve Olgun ve ark. (1999) başakta tane ağırlığının yüksek verimli buğday ırklarının seçiminde seleksiyon kriteri olarak kullanılabileceğini tespit etmişlerdir.

Deshmukh ve ark. (1990) ekmeklik buğdaylarda başakta tane ağırlığının tane verimi üzerine doğrudan etkisinin oldukça yüksek olduğunu belirlemişlerdir.

Araştırmamızda da salkımda tane ağırlığının (\% 41.53) verim üzerine yüksek bir değerde doğrudan etkiyi yaptığı saptanmıştır. Çalışmamızdaki sonuçlarımız Genç (1978), Kumbhar ve ark. (1983), Olgun ve ark. (1999), Deshmukh ve ark. (1990) tarafından bildirilen bulgular ile desteklenmektedir. 


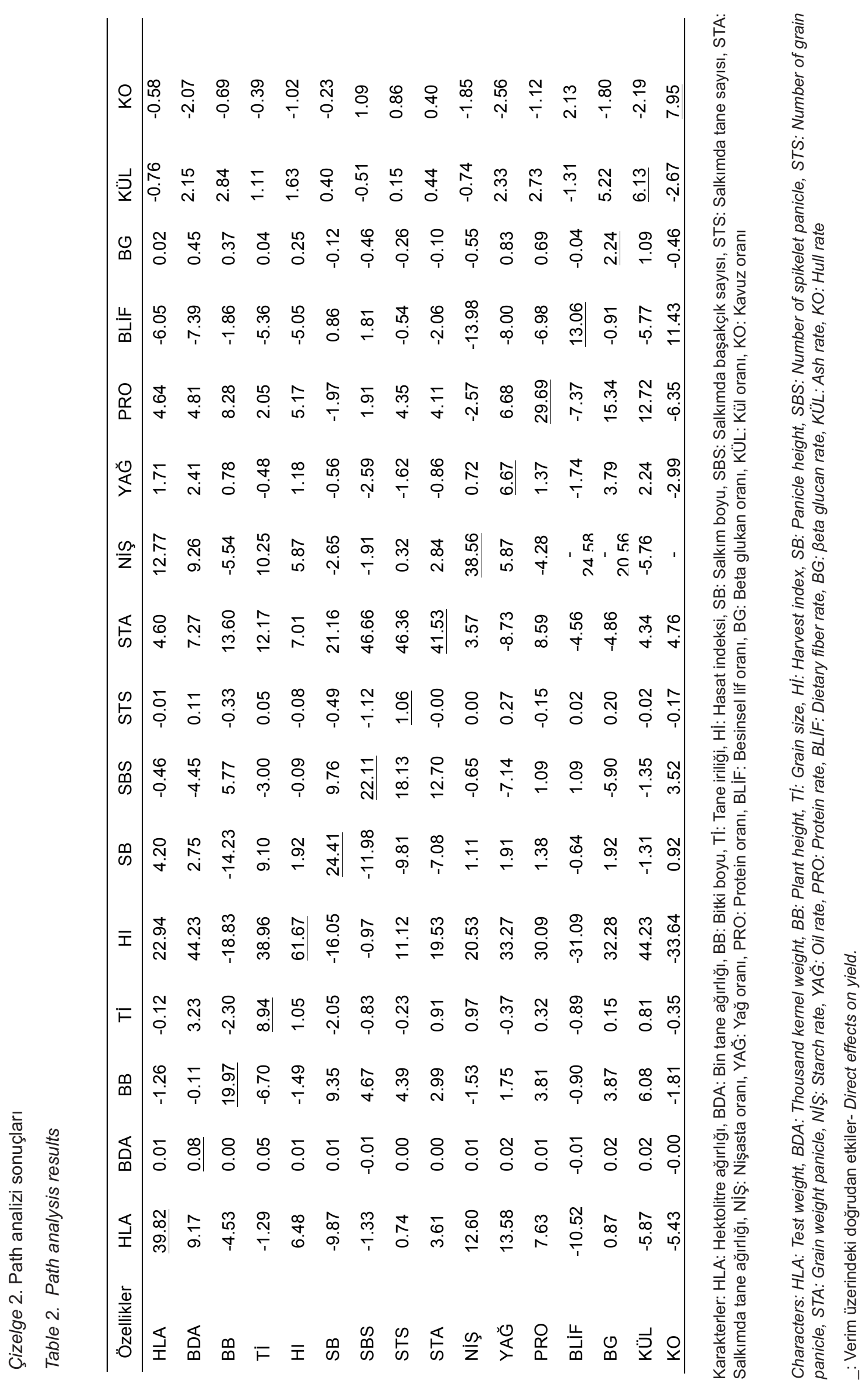




\section{Sonuç}

Verim ile verim öğeleri arasındaki ilişkiler incelendiğinde; tane verimi ile hektolitre ağırlığı, bin tane ağırlığı ve tane iriliği arasındaki korelasyonlar önemli ve pozitif yöndedir. Bununla birlikte, salkımda başakçık sayısı, salkımda tane sayısı ve salkımda tane ağırlı̆ı önemli bulunmuş olup, verim yönünde yapılacak seleksiyonlarda kullanılabileceği söylenebilir. Buna karşın pozitif yönde ve önemli olmak üzere en yüksek korelasyon katsayısı taşıması nedeniyle hasat indeksi dikkati çekmektedir.

Sonuç olarak, yulaf ile birlikte serin iklim tahıllarında hasat indeksine dayalı seleksiyonun etkili olabileceği ve kısa bitki boyunun yatmaya toleransı ve azotlu gübre etkinliğini arttırabileceği söylenebilir.

\section{Teşekkür}

Bu çalışma Nurgül Sarı tarafından Adnan Menderes Üniversitesi Fen Bilimleri Enstitüsü Tarla Bitkileri Anabilim Dalında yapılan yüksek lisans tezinin bir kısmını kapsamaktadır. Tez İzleme Komitesi üyeleri; Prof. Dr. Mehmet Aydın ve Doç. Dr. Osman Erekul ile tezin yürütülmesinde destek sağlayan Ege Tarımsal Araştırma Enstitüsü Müdürlügüne katkılarından dolayı teşekkür ederiz.

\section{Kaynaklar}

Acar Z., 1994. Yulafta kuru ot verimi ile verim komponentleri arasındaki ilişkilerin korelasyon ve path analizi ile belirlenmesi. Anadolu, Journal of AARI 4(2): 55-69

Açıkgöz N., Akbaş M.E., Moghaddam A. ve Özcan K., 1994. PC'ler İçin Veri Tabanı Esasılı Türkçe İstatistik Paketi. 1. Tarla Bitkileri Kongresi. 2428 Nisan, İzmir, s. 264-267

Altınbaş M. ve Sepetoğlu H., 1993. Bir Börülce Populasyonunda Tane Verimini Etkileyen Ögelerin Belirlenmesi Üzerinde Bir Çalışma. Journal of Agricultural and Forestry 17:775-784

Bahl A., Raho S.K. and Singh C.B., 1988. Association analysis of fodder yield and its components in different environments in oats. Crop Improvement 2:132-137.

Bhatt G.M. 1973. Significance of path coefficient analysis in determining nature of character association. Euphytica 22:338-343

Bhutta W.M., Barley T. and Ibrahim M., 2005. PathCoefficient Analysis of Some Quantative Characters in Husked Barley. Caderno de Pesquisa Ser Biologia, Santa Cruz de Sul 17(1):65-70
Buerstmayr H., Krenn N., Stephan U., Grausgruber H. and Zechner E., 2007. Agronomic Performance and Quality of Oat (Avena sativa L.) Genotypes of Worldwide Origin Produced under Central European Growing Conditions. Field Crops Research 101:341351

Choubey R.N. and Gupta S.K., 1986. Correlation and path analysis in forage oat. Indian Journal of Agricultural Science 56(9): 674677

Deshmukh P.W., Atala S.B., Korgade F.W. and Vitrake D.G., 1990. Evaluation of some yield contributing characters under rainfed and irrigated conditions in durum wheat. Annals of Plant Physiology 4(1):80-85

Dewey D.R. and Lu K.H. 1959. A correlation and path coefficient analysis of components of crested wheatgrass seed production. Agronomy Journal 1:515-518

Dofing S.M. and Knight C.W. 1992. Alternative model for path analysis of small grain yield. Crop Science 32:487-489

Dumlupınar Z., Kara R., Dokuyucu T. and Akkaya A., 2008. Correlation and Path Analysis of Grain Yield and Yield Components of some Turkish Oat Genotypes. International Oat Conference, Minneapolis, USA

Genç İ., 1978. Cumhuriyet-75 buğday çeşidinde bitki başına kardeş sayısının verim ve verim unsurları üzerine bir araştırma. Bilimsel Inceleme ve Araştırma Tezleri. Ç.Ü.Z.F. Yayın no: $21: 227$

Gökgöl M., 1969. Serin iklim hububatı ziraatı ve Islahı, s:346-399

Holthaus J.F., Holand J.B., White P.J. and Frey K.J., 1996. Inheritance of $\beta$-glukan content of oat grain. Crop Science 36: 567-572

Iannucci A., Codianni P. and Cattivelli L., 2011. Evaluation of Genotype Diversity in Oat Gerplasm and Definition of Ideotypes Adapted to the Mediterranean Environment. Hindawi Publishing Corporation International Journal of Agronomy. Article ID 870925

Kara B. ve Akman Z., 2007. Yerel buğday ekotiplerinde özellikler arası ilişkiler ve path analizi. Süleyman Demirel Üniversitesi Fen Bilimleri Enstitüsü Dergisi 11(3): 219-224

Kibite S. and Edney M.J. 1998. The inheritance of $\beta$ glukan concentration in three oat (Avena sativa L.) crosses. Canadian Journal of Plant Science 78: $245-250$ 
Kumbhar M.B., Larik A.S., Hafiz H.M. and Rind M.J., 1983. Interrelationship of polygenic traits affecting grain yield in Triticum aestivum $\mathrm{L}$. Wheat Information Services 57: 42-45

Li C.C., 1968. Population Genetics. The University of Chicago Press, Chicago.

Mehetre S. S., Mahajan C.R., Patil P.A., Lad S.K. and Dhumal P.M., 1994. Variability, Heritability, Correlation, Path Analysis, and Genetic Divergence Studies in Upland Rice. IRRN 19(1):8-9

Micke A., 1979. Use of Mutation Induction to Alter the Ontogenetic Pattern of Crop Plants. Gamma Field Symposia 18: 1-23

Mohamed A., 1999. Some statistical procedures for evaluation of the relative contribution for yield components in wheat. Journal of Agricultural Research 2:281-290

Moradi M., Rezai A. and Arzani A., 2005. Path Analysis for Yield and Related Traits in Oats. Journal of Science and Technology of Agriculture and Natural Resources 9(1): 173180

Olgun M., Partigöç F. ve Yıldırım T., 1999. Erzurum şartlarında buğday ıslahında tartılı derecelendirme yönteminin kullanılması. Orta Anadolu' da Hububat Tarımının Sorunları ve Çözüm Yolları Sempozyumu, 8-11 Haziran, Konya, s. 70-76
Öztürk A. ve Atken Ş., 1999. Kışlık buğdayda bazı morfofizyolojik karakterler ve tane verimine etkileri. Turkish Journal of Agriculture and Forestry 23:531-540

Peterson D.M., Wesenberg D.M., and Burrup D.E. 1995. $\beta$-glukan content and its relationship to agronomic characteristics in elite oat germplasm. Crop Science 35:965-970

Ram T., 1992. Character Association and Path Coefficient Analysis in Rice Hybrids and their Parents. Journal of Andaman Science Association 8(1):26-29

Redaelli R., Lagana P., Rizza F., Li Destri Nicosia O. and Cattivelli L., 2008. Genetic progress of oats in Italy. Euphytica 3: 679-687

Samonte S.O.PB., Wilson L.T. and Mcclung A.M. 1998. Path Analyses of Yield and YieldRelated Traits of Fifteen Diverse Rice Genotypes. Crop Science 38:1130-1136

Sürek H., Korkut Z.K. and Bilgin O., 1998. Correlation and Path Analysis for Yield and Yield Components in Rice in A 8-Parent Half Diallel Set of Crosses. Oryza 35(1): 15-18

Yang H.S., 1986. Studies on the Main Traits of Inter Varietals Hybrid Progenies in Indica Rice. Fujan-Agricultural Science and Technology 6: $2-4$ 